\title{
A new approach to mark termites (Cornitermes cumulans (Kollar) Blattodea: Isoptera) for laboratory bioassays
}

\author{
Uma nova abordagem de marcador tópico em cupins para bioensaios de laboratório
}

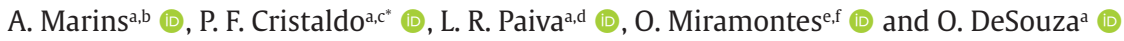 \\ aUniversidade Federal de Viçosa - UFV, Departamento de Entomologia, Laboratório de Termitologia, Viçosa, MG, Brasil \\ bUniversidade Federal de Viçosa - UFV, Departamento de Solos, Viçosa, MG, Brasil \\ 'Universidade Federal Rural de Pernambuco - UFRPE, Departamento de Agronomia, Programa de Pós-Graduação em Entomologia, Laboratório \\ de Insetos Sinantrópicos, Recife, PE, Brasil \\ dUniversidade Federal de São João Del-Rei - UFSJ, Ouro Branco, MG, Brasil \\ eUniversidad Nacional Autónoma de México, Instituto de Física, Departamento de Sistemas Complejos, Ciudad de México, México \\ fUniversidad Nacional Autonoma de México,Centro de Ciencias de la Complejidad - C3, Ciudad de México, México
}

\begin{abstract}
Behavioral lab bioassays involving termites must be promptly performed to allow intended observations prior to death from dissecation, typical of these soft-bodied insects. To this end, topic markers have been proposed as an alternative to histological stains which, while not always toxic are inevitably lengthy to apply. Among recommended topic markers, gouache is easy to apply, dries out quickly, but it is known affect termites in the long run, being suitable only to short-term bioassays. Its alternative, colored glue, is also easy to apply, but it takes long to dry and it is too dense and heavy, being thus prone to affect termite walking patterns. Here we tested a mix of gouache and colored glue aiming to combine the qualities of both into a suitable topical marker for Cornitermes cumulans termites. Similar patterns of survival presented by marked and unmarked termites ruled out concerns about toxicity of this mixture. Such results were consistent across distinct group densities evidencing that the mixture does not interfere with, nor it is affected by, crowding effects. Because crowding regulates interindividual interactions and these underlie most behaviors, the mixture can be thought to be suitable to behavioral studies. We argue that this 1:2 glue:gouache mixture is an excellent alternative to mark termites for lab bioassays. Being atoxic, cheap, easy to apply, and non-invasive, this mixture may happen to be useful not only for termites but also in bioassaying other similarly soft-bodied insects.
\end{abstract}

Keywords: bioassays, behaviour, biological dyes, termite survival, toxicity.

\begin{abstract}
Resumo
Bioensaios comportamentais em laboratório com cupins devem ser realizados rapidamente a fim de garantir observações antes da morte por dissecação, típico desses insetos de corpo mole. Para este fim, marcadores tópicos têm sido propostos como uma alternativa para marcadores histológicos que, embora nem sempre tóxico, possuem uma aplicação demorada. Entre os marcadores tópicos recomendados, tinta guache é de fácil aplicação, rápida secagem, porém afeta os cupins em bioensaios longos, sendo adequado apenas para bioensaios curtos. Sua alternativa, cola colorida, também é de fácil aplicação mas leva muito tempo para secar e é muito denso e pesado, afetando os padrões de caminhamento dos cupins. No presente estudo, nós testamos uma mistura de tinta guache e cola colorida objetivando combinar as qualidades de ambos os marcadores tópicos em um marcador tópico adequado para Cornitermes cumulans. Padrões similares de sobrevivência entre cupins marcados e controle indicam a ausência de toxicidade na mistura de tinta guache e cola colorida. Tais resultados são consistentes em grupos de densidades distintas, o que comprova que a mistura não interfere, nem sofre efeitos de aglomeração. Uma vez que a aglomeração regula as interações inter-individuais e afetam a maioria dos comportamentos, a mistura pode ser adequada para estudos comportamentais. Nós argumentamos que a mistura de tinta guache e cola (1:2) é uma excelente alternativa como marcador tópico em cupins para bioensaios em laboratório. Sendo atóxico, barato, fácil de aplicar e não invasivo, esta mistura pode ser útil não só para os cupins, mas também em bioensaios com outros insetos de corpo mole.
\end{abstract}

Palavras-chave: bioensaios, comportamento, marcadores biológicos, sobrevivência de cupins, toxicidade.

*e-mail: pfellipec@gmail.com

Received: March 10, 2016 - Accepted: May 30, 2016

This is an Open Access article distributed under the terms of the Creative Commons Attribution License, which permits unrestricted use, distribution, and reproduction in any medium, provided the original work is properly cited. 


\section{Introduction}

Despite the well-known termite importance as pest (Su, 2002) and their key role in nutrient cycle (Alho, 2008; DeSouza et al., 2009; Pringle et al., 2010), basic aspects of termite biology and ecology remain open to investigation. For instance, while inter-individual communication has been extensively studied in Hymenoptera, it has only very recently been discovered that vibratory signals are important cues to the efficient use of resources by termites (Evans et al., 2009) and that alarm communication in this group integrate chemical and vibroacoustic signals (Cristaldo et al., 2015). Methodological barriers on how to deal with cryptic individuals adapted to environments with low-light condition, controlled humidity and temperature may account for such a lack of knowledge (Lenz, 2009). Given that, new protocols designed to investigate basic aspects of termite biology are needed.

Bioassays have been used as a powerful tool in the study of behavioral ecology, whereby it is possible to obtain responses of model organisms against different intrinsic and/or extrinsic stimuli (Hoskins and Craig, 1962). They can also provide relevant information about mechanisms involved in the walking pattern of organisms during foraging (e.g. Nobre et al., 2007), sexual partners, nesting site and/or estimation of population (e.g. Su et al., 1991; Evans et al. 1998). Many of such assays rely on markers to identify the individual observed, allowing a better control of experiments and accurate observations (Hagler and Jackson, 2001).

Cryptic habits exhibited by termites often require behavioral bioassays to be performed under laboratory condition. In such cases, a termite group is confined in an experimental arena and the behavior studied is obtained from observation or video recording of one or more individuals identified by artificial markers. When out of their nests, termites are however highly prone to desiccation and death, due their weakly chitinized and very fragile bodies. Special, harmless, and easy to apply, markers are therefore needed. Currently, two types of markers are used for termites: (i) histological stains such as Sudan Red 7B, Nile Blue A or Neutral Red (Su et al., 1991; Evans et al., 1998; Nobre et al., 2007) and (ii) topic markers: gouache (Brunow et al., 2005) and colored glue (Loreto et al., 2009).

While extensively used to mark termites, histological stains are hampered by the need to wait their ingestion by the individuals to be assayed. This method increase the time individuals spend outside their nest, enhancing mortality while allegedly affecting their normal behavior. In addition, some stains (e.g. Sudan Blue 35) are harmful to termites (Grace and Abdallay, 1990) and most of them do not provide enough contrast, impairing video-recordings. For such assays, a topic marker applied directly on the individuals' abdomen seems to be a better alternative but current techniques still need improvement. Gouache topic markers are easy and quickly applied, but have proven to be harmful for Cornitermes cumulans (Kollar) (Termitidae, Syntermitinae) workers $300 \mathrm{~min}$. after application (Brunow et al., 2005). Because such a harm seemed not to origin from intoxication, Brunow et al.
(2005) have recommended is use, but only for short-term assays. In contrast, colored glue did not present any harm for workers of this same species (Loreto et al., 2009) being therefore indicated for bioassays involving survival. Such as glue, however, is dense and relatively heavy for a termite individual, impairing termite walking behavior (Marins A. personal observation). In addition, colored glues are lengthy to dry completely (up to $40 \mathrm{~min}$ ) which increases individuals' desiccation and proneness to death.

In this study, we aimed to establish a new marking technique suiting the needs of live observation and videorecording of termite behavior in laboratory bioassays. We test the hypothesis that mixing gouache and colored glue would combine the qualities of both, resulting in a topic marker easy and quick to apply, which does not affect termite movement and survival. To this end, we compared the survival of $C$. cumulans workers unmarked and marked with a mixture of gouache and colored glue. Because termite survival depends strongly on group density (Miramontes and Desouza, 1996; DeSouza et al., 2001) we performed bioassays in three different densities: uncrowded, optimal and crowded. We conclude that the new technique proposed here meets current biological and practical demands of bioassays involving marked termites, and recommend its use in bioassays.

\section{Material and Methods}

In order to verify the suitability of the use of gouache and colored glue mixture as a topic marker on termites, survival bioassays were performed using workers (third instar and beyond) collected from field colonies of $C$. cumulans $(N=3)$, in Viçosa, state of Minas Gerais, in southeastern Brazil. Cornitermes spp. are Neotropical termite species occurring in several habitats, including forests, "Cerrados" (Brazilian savannas) and man-modified habitats, such as pastures or even gardens within cities, where they feed on living and dead grass and herbs (Cancello, 1989).

As soon as mound fragments were taken to the laboratory, C. cumulans workers were extracted and arbitrarily placed in groups of 10, 15 and 20 individuals (each group replicated three times). Groups were confined in glass Petri dishes ( $\varnothing 53 \mathrm{~mm}$ ) laid upside down over a sand-blasted flat glass (see Figure 1). Density was measured as the total area occupied by termite individuals divided by total area of Petri dish, hence resulting in (i) uncrowded, 10 individuals - density 0.08 , (ii) optimal, 15 individuals - density 0.12, and (iii) crowed, 20 individuals - density 0.18 (Miramontes and Desouza, 1996; DeSouza et al., 2001; DeSouza and Miramontes, 2004). After that, individuals were anesthetized on ice for approximately three minutes before the marking procedure, which consisted in painting all individuals of each group with a mixture of: (i) black gouache plus black colored glue (Black marker), or (ii) white gouache plus white colored glue (White marker). Unmarked termites composed the control group. We used commercially available, atoxic to humans, water soluble gouache (Tempera Guache Acrilex $^{\circledR}$ ) and colored glue (Aplicola GR Química Ind. Com. Ltda $\left.{ }^{\circledR}\right)$. Gouache contained 1-6\% organic pigments, 
$2-5 \%$ vinyl copolymer in aqueous dispersion, $15-25 \%$ inert minerals, and 0.1-0.3\% isothiazols (CAS 55965-84-9) plus nitropropane (CAS 52-51-7). The colored glue contained pigments, gum arabic with preservatives and glycerin. Individuals were painted dorsally (on abdominal tergites) with a mixture of 1:2 glue:gouache on the abdomen, and special care was taken to avoid obstructing spiracles and to avoid gluing legs and/or antennae. The control group did not receive the mixture of gouache and colored glue but it was otherwise manipulated in a similar manner to the marked groups, in order to control the effects of handling.

Observations started as soon as all individuals in the group had been marked or handled, and proceeded every one hour between 10 am and 9 pm until all individuals were dead. Termite groups were placed in the dark in a climate chamber $\left(25^{\circ} \mathrm{C} \pm 0.05\right)$ and no food or water was

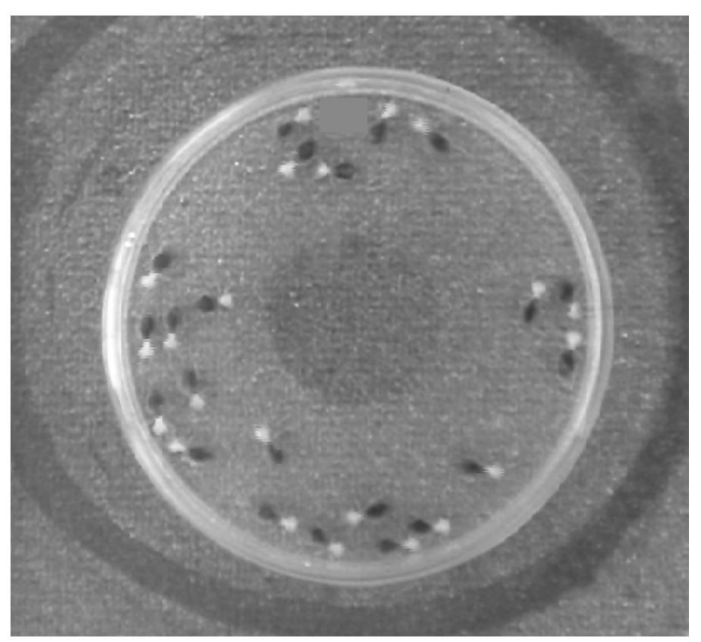

Figure 1. Photo of an experimental arena used for bioassays with sand-blasted flat glass as walking area and a Petri dish laid upside down. provided. Petri dishes were exposed to light only during the counting of survivors (no more than $5 \mathrm{~min}$ ). Voucher specimens were preserved in $80 \%$ ethanol, labeled and subsequently identified by comparison with the collection of the Termite Section of the Entomological Museum of the Federal University of Viçosa (MEUV), Viçosa, Brazil. This work was carried out in May/2014.

Censored Survival Regression Analysis with Weibull model distribution (Crawley, 2007) was used to verify whether survival patterns differed between marked and unmarked treatments, i.e., workers marked with Black mixture, White mixture, and unmarked workers. Analyses were performed independently for each density (uncrowded, optimal and crowded situations), and included 'Petri Dish' and 'colony' as a blocking factor. Comparisons between treatments were conducted through contrast analyses with $F$ test, removing non-significant $(P<0.05)$ terms sequentially, starting from the most complex one and then lumping treatments levels together within retained categorical variables. Analyses were performed used survival package on R Software (R Development Core Team, 2011).

\section{Results}

In general, termite survivorship was not significantly affected neither by markers nor densities tested here $\left(\chi^{2}=0.20, p=0.985\right)$. In all of three densities (uncrowded, optimal and crowded), both colors of markers tested, black and white, did not cause significant decrease in the meantime to death of termite workers compared with control treatment (Figure 2; Table 1). On average, termites in uncrowded densities $(d=0.08)$ survived $585.03 \mathrm{~min}$., those on optimal $(d=0.12)$ survived 876.27 min., while workers in crowded groups $(\mathrm{d}=0.17$ ) survived $877.37 \mathrm{~min}$. The mean time to death of $C$. cumulans workers in each density and treatments tested is summarized in Table 1.

No cannibalism, aggression or rejection behavior were observed before placing termite's groups in the climate

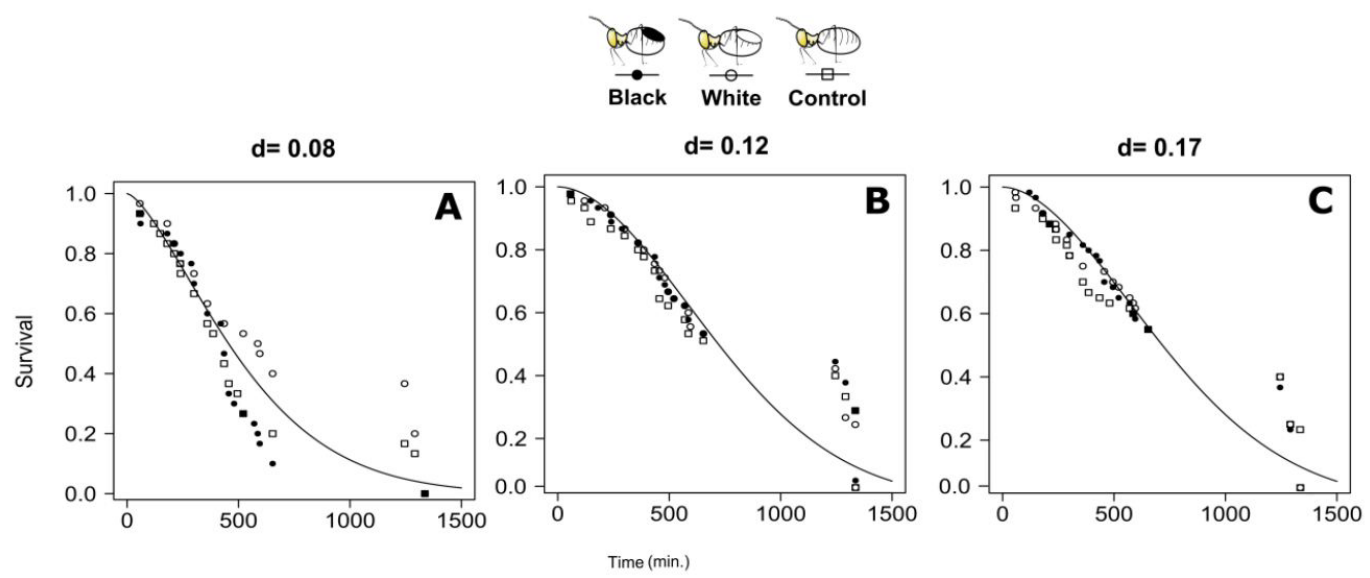

Figure 2. Survival curves for Cornitermes cumulans (Termitidae, Syntermitinae) workers marked with a 1:2 mixture of similarly colored gouache and glue ("Black" and "White") and workers that did not receive any mixture ("Control"). Left panel (A) shows survival curves for uncrowded groups (density, $d=0.08$ ), mid panel (B) refers to groups in optimal densities $(d=0.12$ ) and right panel (C) depicts crowded groups $(\mathrm{d}=0.17)$. No significant differences were found between curves within each panel (see text for details). 
Table 1. Mean time to death and shape parameter $(\alpha)$ of survival curve for Cornitermes cumulans (Termitidae: Syntermitinae) individuals submitted to different topic marking treatments, confined in Petri dishes, in groups of a given density. Density is defined as the total area occupied by all termites in a group divided by the area of the dish. Treatments consisted in a 1:2 mix of similarly colored gouache and glue, to form either a black or a white marker which was applied onto termite abdominal tergites. See Material \& Methods for more details.

\begin{tabular}{|c|c|c|c|c|c|}
\hline Density & Treatment & $\begin{array}{l}\text { Mean time to death } \\
(\text { min.) }\end{array}$ & $\alpha$ & $\chi^{2}$ & $\boldsymbol{P}$ \\
\hline \multirow{3}{*}{ Uncrowded $(\mathrm{d}=0.08)$} & Control & 478.49 & \multirow{3}{*}{1.45} & \multirow{3}{*}{30.24} & \multirow{3}{*}{$0.45 n . s$} \\
\hline & Black marker & 476.04 & & & \\
\hline & White marker & 527.42 & & & \\
\hline \multirow{3}{*}{ Optimal $(\mathrm{d}=0.12)$} & Control & 889.04 & \multirow{3}{*}{1.87} & \multirow{3}{*}{6.33} & \multirow{3}{*}{0.99 n.s } \\
\hline & Black marker & 887.29 & & & \\
\hline & White marker & 1000.32 & & & \\
\hline \multirow{3}{*}{ Crowded $(\mathrm{d}=0.17)$} & Control & 879.37 & \multirow{3}{*}{1.82} & \multirow{3}{*}{5.50} & \multirow{3}{*}{0.99 n.s } \\
\hline & Black marker & 877.19 & & & \\
\hline & White marker & 988.28 & & & \\
\hline
\end{tabular}

$\mathrm{C}=$ Control; $\mathrm{BM}=$ Black marker; $\mathrm{WM}=$ White marker - n.s. No significant statistic differences $(P>0.05)$.

chamber and during the counting of survivors. At the end of survival bioassays, all marked workers remained marked. The mixture of gouache and colored glue took less than $10 \mathrm{~min}$. to dry and no effect was observed in the walking of workers marked with the mixture compared with unmarked individuals.

\section{Discussion}

An ideal topic marker for insects should be durable, non-toxic, light, easy and quick to apply (Walker and Wineriter, 1981; Hagler and Jackson, 2001). All these aspects could be observed in the mixture of gouache and colored glue tested here, proving it to be a good alternative as a marker for termites in laboratory bioassays. Marking termites with such a mixture did not affect their survival (as compared to unmarked ones) and this was consistent across all different densities in which termites were confined (Figure 2). In addition, the mixture has proved itself easy to apply on termites and quick to dry allowing prompt bioassay setup.

Among the advantages of this mixture, reduction in the time to mark individuals appears paramount. Histological stains, being administered by forcing termites to feed on filter paper in the lab, require from three to 10 days to allow accurate observations (Evans, 2000). Under such circumstances, however, termites seem to become less vigorous (Curtis and Waller, 1997), most likely suffering changes in behavior and survival. External topic markers would then seem to be a better alternative as they are quickly applied, consequently allowing prompt observations. Among these, the glue: gouache mixture here proposed prevails as the fastest to dry while keeping workability typical of such markers. While this mixture takes around $10 \mathrm{~min}$ to dry, colored glue alone would take 30 min (Loreto et al., 2009). The consequent reduction in the time between termite collection in the field and the beginning of the experiment is likely to mitigate the unavoidable burden of keeping termites away from their colonial environment, hence increasing accuracy to the study. It should also enhance the chances to carry out intended observations prior to eventual death of assayed termites.

Additionally, termites marked with such a mixture and those unmarked survived alike, differently from those assayed with gouache alone by Brunow et al. (2005). Survival of the latter was affected 300 min. after marking. Because both assays -- Brunow's and ours -- used the same gouache brand, differences in toxicity between markers cannot explain such distinct results. Toxicity should be also not an issue when comparing our results to Loreto's et al. (Loreto et al., 2009), as termites in neither of these assays presented any evidence of intoxication. Harmlessness of our proposed mixture seems in fact to arise from its physical traits: it is, at the same time, comparatively denser than gouache alone and lighter than glue alone. That is to say, when applied to tergites, this mixture would ooze less than gouache to termite's side while being not burdensome on the back of individuals. As a consequence, risks of spiracles' obstruction would be reduced and normal walking patterns could be kept in assayed termites.

Consistency of results across distinct group densities (Table 1, Figure 2) adds further reliability to the technique here proposed. As with other organisms, termites are known to adjust inter-individual interactions according to the crowding context (Miramontes and Desouza 1996; Miramontes and DeSouza, 2008), resisting intoxication if confined in optimal densities (DeSouza et al., 2001). Since marked individuals did not differ from unmarked ones across all group densities assayed, the marking technique cannot be said to interfere with, or be affected by, behavioral traits. It is thus, safe to recommend its use in termite behavioral assays.

In conclusion, combining both markers proposed by Brunow et al. (2005) and Loreto et al. (2009) into a 1:2 glue: 
gouache mixture has proven to be an excellent alternative to mark termites for lab bioassays. It has solved, at the same time, major hindrances known to these techniques, providing a protocol that allows individual marking in termite workers without interference with their survival or their walking behavior. Being atoxic, cheap, easy to apply, and non-invasive, this mixture may happen to be useful not only for termites but also in bioassaying other similarly soft-bodied insects such as endopterygotan larvae.

\section{Acknowledgements}

We thank H. H. dos Santos and L.F. Nunes for help during bioassays preparation. This research was funded by Coordination for the Improvement of High Education Personal (CAPES) - Science without Borders Program (PVE-CAPES 0148/2012), which also provided postdoctoral grants to AM, LRP, and PFC and a visiting professorship to OM. ODS holds a Research Fellowship from CNPQ (PQ $305736 / 2013-2)$. This is contribution no. 68 from the Termitology Lab at Federal University of Viçosa, Brazil. This paper was entirely produced using free software, including GNU Linux, Ubuntu, R, LibreOffice among others.

\section{References}

ALHO, C.J.R., 2008. The value of biodiversity. Brazilian Journal of Biology = Revista Brasileira de Biologia, vol. 68, no. 4, suppl., pp. 1115-1118. PMid:19197481. http://dx.doi.org/10.1590/S151969842008000500018

BRUNOW, G.S., DESOUZA, O. and MIRAMONTES, O., 2005. Commercial gouache as a dye for termites in laboratory assays. Brazilian Archives of Biology and Technology, vol. 48, no. 4, pp. 575-579. http://dx.doi.org/10.1590/S1516-89132005000500010.

CANCELLO, E.M., 1989. Revisão de Cornitermes Wasmann (Isoptera, Termitidae, Nasutitermitinae). São Paulo: Universidade Federal de São Paulo, 220 p. Tese em Ciências Biológicas (Zoologia).

CRAWLEY, M.J., 2007. The R book. West Sussex: John Wiley and Sons.

CRISTALDO, P.F., JANDÁK, V., KUTALOVÁ, K., RODRIGUES, V.B., BROTHÁNEK, M., JIŘÍČEK, O., DESOUZA, O. and ŠOBOTNÍK, J., 2015. The nature of alarm communication in Constrictotermes cyphergaster (Blattodea: Termitoidea: Termitidae): the integration of chemical and vibroacoustic signals. Biology Open, vol. 4, no. 12, pp. 1649-1659. PMid:26538635. http://dx.doi. org/10.1242/bio.014084.

CURTIS, A.D. and WALLER, D.A., 1997. Variation in rates of nitrogen fixation in termites: response to dietary nitrogen in the field and laboratory. Physiological Entomology, vol. 22, no. 4, pp. 303-309. http://dx.doi.org/10.1111/j.1365-3032.1997.tb01173.x.

DESOUZA, O. and MIRAMONTES, O., 2004. Non-Asymptotic Trends in the Social Facilitated Survival of Termites (Isoptera). Sociobiology, vol. 44, pp. 1-12.

DESOUZA, O., ARAÚJO, A.P.A. and REIS-JR, R., 2009. Trophic controls delaying foraging by termites: reasons for the ground being brown? Bulletin of Entomological Research, vol. 99, no. 6, pp. 603-609. PMid:19302722. http://dx.doi.org/10.1017/ S000748530900666X.

DESOUZA, O., MIRAMONTES, O., SANTOS, C.A. and BERNADO, D.L., 2001. Social facilitation affecting tolerance to poisoning in termites (Insecta, Isoptera). Insectes Sociaux, vol. 48, no. 1, pp. 21-24. http://dx.doi.org/10.1007/PL00001739.

EVANS, T.A., 2000. Fast marking of termites (Isoptera: Rhinotermitidae). Sociobiology, vol. 36, pp. 517-523.

EVANS, T.A., INTA, R., LAI, J.C.S., PRUEGER, S., FOO, N.W., FU, E.W. and LENZ, M., 2009. Termites eavesdrop to avoid competitors. Proceedings of the Royal Societies - Biological Sciences, vol. 276, no. 1675, pp. 4035-4041. http://dx.doi.org/10.1098/rspb.2009.1147.

EVANS, T.A., LENZ, M. and GLEESON, P.V., 1998. Testing assumptions of mark-recapture protocols for estimating population size using Australian mound-building, subterranean termites. Ecological Entomology, vol. 23, no. 2, pp. 139-159. http://dx.doi. org/10.1046/j.1365-2311.1998.00114.x.

GRACE, J.K. and ABDALLAY, A., 1990. A short-term dye for marking eastern subterranean termites (Reticulitermes flavipes Koll.) (Isoptera, Rhinotermitidae). Journal of Applied Entomology, vol. 109, no. 1-5, pp. 71-75. http://dx.doi. org/10.1111/j.1439-0418.1990.tb00020.x.

HAGLER, J.R. and JACKSON, C.G., 2001. Methods for marking insects: current techniques and future prospects. Annual Review of Entomology, vol. 46, no. 1, pp. 511-543. PMid:11112178. http:// dx.doi.org/10.1146/annurev.ento.46.1.511.

HOSKINS, W.M. and CRAIG, R., 1962. Uses of bioassay in entomology. Annual Review of Entomology, vol. 7, no. 1, pp. 437-464. PMid:14449182. http://dx.doi.org/10.1146/annurev. en.07.010162.002253.

LENZ, M., 2009. Laboratory bioassays with subterranean termites (Isoptera) - the importance of termite biology. Sociobiology, vol. 53, pp. 573-595.

LORETO, R.G., DESOUZA, O. and ELLIOT, S.L., 2009. Colored glue as a tool to mark termites (Cornitermes cumulans; Isoptera. Termitidae) for ecological and behavioral studies. Sociobiology, vol. 54, pp. 351-360.

MIRAMONTES, O. and DESOUZA, O., 1996. The nonlinear dynamics of survival and social facilitation in termites. Journal of Theoretical Biology, vol. 181, no. 4, pp.373-380. http://dx.doi.org/10.1006/ jtbi.1996.0138.

MIRAMONTES, O. and DESOUZA, O., 2008. Individual basis for collective behaviour in the termite, Cornitermes cumulans. Journal of Insect Science, vol. 8, no. 22, pp. 1-11. PMid:20233076. http://dx.doi.org/10.1673/031.008.2201.

NOBRE, T., NUNES, L. and BIGNELL, D.E., 2007. Estimation of foraging territories of Reticulitermes grassei through mark release recapture. Entomologia Expimentalis at Applicata, vol. 123, no. 2, pp. 119-128. http://dx.doi.org/10.1111/j.1570-7458.2007.00530.x.

PRINGLE, R.M., DOAK, D.F., BRODY, A.K., JOCQUÉ, R. and PALMER, T.M., 2010. Spatial pattern enhances ecosystem functioning in an African savanna. PLoS Biology, vol. 8, no. 5, pp. e1000377. PMid:20520846. http://dx.doi.org/10.1371/journal.pbio.1000377.

R DEVELOPMENT CORE T.E.A.M., 2011. $R$ : a language and environment for statistical computing. Vienna: R Foundation for Statistical Computing.

SU, N.Y., 2002. Novel technologies for subterranean termite control. Sociobiology, vol. 40, pp. 95-101.

SU, N.Y., BAN, P.M. and SCHEFFRAHN, R.H., 1991. Evaluation of twelve dye markers for population studies of the eastern and Formosan subterranean termite (Isoptera: Rhinotermitidae). Sociobiology, vol. 19, pp. 349-362.

WALKER, T.J. and WINERITER, S.A., 1981. Marking techniques for recognizing individual insects. The Florida Entomologist, vol. 64, no. 1, pp. 18-29. http://dx.doi.org/10.2307/3494598. 